\title{
Return to Campus? Amid the COVID-19 Pandemic?
}

\author{
Mary E. Ogidigben \\ Kennesaw State University \\ Ernesto R. Rivera \\ Kennesaw State University \\ Robert S. Keyser \\ Kennesaw State University
}

A descriptive research design was employed at a major university, Kennesaw State University, during the Fall 2020 semester to explore how the campus community felt about the cleanliness and safety in the campus environment during the COVID-19 pandemic. The research team consisted of a full-time industrial engineering professor and two senior-level industrial engineering students. Results reveal that the majority of respondents felt a general sense of feeling safe when returning to campus during Fall 2020. The majority respondents had also received their KSU-branded cloth face mask by the time they took the survey. Half of the respondents indicated a feeling that KSU had taken appropriate steps to ensure multiple daily cleanings of high-traffic areas and nearly half of the respondents felt that high-touch surfaces were being cleaned frequently enough to prevent COVID-19 from spreading. Finally, other concerns shared by respondents include changes in stress level, worry, limited student interaction, social distancing issues, poor planning, and distrust of the KSU administration.

Keywords: COVID-19, coronavirus, cleanliness, safety

\section{INTRODUCTION}

Kennesaw State University (KSU) is a four-year R2 university with a student enrollment of over 41,000 students. KSU has two campuses: in Kennesaw, Georgia and Marietta, GA. Our goal is to share our findings via a survey that was offered to students, faculty, staff, and administrators regarding their perceptions of the cleanliness and safety on our campuses during the COVID-19 pandemic.

The University System of Georgia (USG) determined that if Georgia schools followed the safety guidelines set forth by the Centers for Disease Control and Prevention (CDC), students should be given the opportunity to return to campus for the Fall 2020 semester. As a part of the USG, Kennesaw State University made the decision to allow students to return to campus while working with faculty members to determine the safest way to deliver classes. This resulted in most professors delivering online and hybrid (50\% online, $50 \%$ in-person) classes with very few traditional in-person classes.

During Summer 2020, members of the Presidential Task Force created guidelines for a safe return to campus for students $\left(\mathrm{KSU}^{1}, 2020\right)$ and faculty and staff $\left(\mathrm{KSU}^{2}, 2020\right)$. These guidelines include 
preventative practices in the workplace, advising people to stay home if they felt any number of listed symptoms associated with the coronavirus as defined by the Department of Public Health, health conditions that may be classified as "high-risk", staffing options, health and safety guidelines (i.e., face masks, social distancing, frequent handwashing), conducting online meetings, advising that high-traffic areas would be professionally cleaned multiple times daily, the provision of hand sanitation stations in all buildings across campus, and contact information for the Centers for Disease Control, Department of Public Health, and KSU.

This descriptive IRB-approved study will provide an understanding of how the KSU community felt about the cleanliness and safety of the campus environment. The survey was administered during the first few weeks upon returning to campus during the semester via KSU Today, a daily online medium that KSU uses post Announcements of interest to the KSU community.

The research team consisted of a full-time Industrial Engineering professor and two senior-level Industrial Engineering students in the university's Southern Polytechnic College of Engineering and Engineering Technology (SPCEET). This particular research design was selected because it allowed the researchers to obtain insight via survey questions that participants could anonymously respond to on a voluntary basis; that is, all personally identifiable information was removed from participant responses. The significance of this study is that other academic institutions could gain insight into how KSU successfully provided a clean and safe campus environment and, perhaps, adopt ideas for their own institutions.

Our research questions are as follows:

RQ1: Do you feel safe coming to the KSU campus?

RQ2: Have you received a branded KSU cloth face mask?

RQ3: Do you feel that KSU has taken appropriate steps to ensure multiple daily cleaning of high-traffic areas?

RQ4: Do you feel that the high-touch surfaces are being cleaned often enough to prevent COVID-19 from spreading?

RQ5: What changes have impacted you the most on-campus due to COVID-19?

\section{LITERATURE REVIEW}

Reports of the COVID-19 coronavirus first surfaced in December 2019 (Borowiak et al., 2020) but gained worldwide attention in January 2020 when the World Health Organization (WHO) declared the COVID-19 outbreak a "public health emergency of international concern" (Kennedy, 2020). In February 2020, the Centers for Disease Control (CDC) provided guidelines on how to protect yourself and others (Centers for Disease Control, 2020). On March 11, 2020, the Director General of the World Health Organization characterized COVID-19 as a pandemic in his opening remarks at a media briefing (WHO, 2020).

This had a profound impact on the world at-large but also on college and university campuses during the Spring 2020 semester, over the summer, and leading to the Fall 2020 semester, the beginning of a new academic year. With new coronavirus cases ramping up over the summer months, many questioned why colleges and universities wanted students to return to campus in the Fall. Many schools took the position that Northeastern University assumed - principally, that both students wanted to return to campus and their parents wanted them on campus, too (Aoun, 2020). Conversely, institutions of higher learning face enormous financial pressures to bring students back on campus (Nocera, 2020; PRI, 2020). However, the return to campus did not come without many inherent risks. For example, many faculty members across the 
U.S. expressed grave doubts regarding their institutions' ability to safely bring students and staff together (Marek, 2020).

Many universities, such as the University of Alabama, the University of Southern California, The Ohio State University, and universities in Britain (PRI, 2020) rolled back campus reopening plans due to COVID19 outbreaks. Some universities, such as the University of North Carolina - Chapel Hill, Notre Dame University, and Michigan State University allowed students to move back on campus and then immediately asked students to leave campus due to a COVID-19 outbreak (Raimonde, 2020; Weekend Edition Sunday, Aug 2020; Camera, 2020; Grayer \& Stuart, 2020). Examples of outbreak countermeasures implemented by universities include asking students and faculty to self-quarantine (Diep, 2020), providing mobile phone apps that allows users who test positive for COVID-19 to upload a magic key to alert other people which pings were dangerous and which ones were not (PR Newswire, July 2020; Weekend Edition Sunday, Sept 2020), moving all face-to-face lectures to fully online lectures for the coming academic year (Vaghela, 2020). Many universities view testing students for the COVID-19 as the only safe way to bring students back on campus (Court \& Lorin, 2020). Many schools have provided COVID-19 guidelines for a safe return to campus, although the concern that some schools may not follow the plan is prevalent (All Things Considered, Sept 2020).

Despite such countermeasures, there has been an increase in new coronavirus cases at institutions around the world. Despite mass testing at the University of Illinois, hundreds of asymptomatic cases have surfaced, mostly among undergraduate students (Weekend Edition Sunday, Aug 2020; Nadworny \& Inskeep, 2020). Virus clusters have appeared at universities in France (Corbet \& Siegel, 2020). Fall coronavirus outbreaks have been linked to student fraternities and sororities (Reilly, 2020).

Issues that have surfaced on college campuses during the COVID-19 pandemic include modifying facilities such as libraries (Dixon, 2020), addressing the needs of college students with special needs (Gould, 2020), managing the mental health of students (Aufderheide \& Gondles, 2020), athletes (Roetert, Bell, \& Hainline, 2020), and people, in general (Shuja et al., 2020), protecting the safety and well-being of the student LGBTQ+ community (Wood, 2020; Weissman, 2020), and the effects and added responsibilities absorbed by the faculty (Alexander, 2020).

\section{METHODOLOGY}

The data collection method was an online survey that was created using Qualtrics XM and then posted in the Kennesaw State University's system for posting announcements, KSU Today, so students, faculty, staff, and administrators could voluntarily complete it. All participants were given the option to skip questions or simply opt out of the survey without consequence. The survey consisted of eighteen Likert scale questions (where " 1 " = strongly agree and " 6 " = strongly disagree) and eight free response questions. This paper shares results for five of those questions, all pertaining to the cleanliness and safety on campus. At the end of the survey period, descriptive statistics generated by Qualtrics XM were used to analyze the answers to the Likert scale questions while the detailed responses to the free-response questions were categorized by the researchers.

\section{RESEARCH FINDINGS}

Our findings to the research questions are provided below.

\section{RQ1: Do you feel safe coming to the KSU campus?}

As shown in Table 1 below, whereas nearly 40\% Strongly Agree with feeling safe coming to the KSU campus early in the Fall 2020 semester when the survey was administered, $70.8 \%$ (34 out of 48 responses) of the responses indicated either Somewhat Agree or Strongly Agree. 
TABLE 1

RESPONSES TO RQ1: DO YOU FEEL SAFE COMING TO THE KSU CAMPUS?

\begin{tabular}{|c|c|c|c|c|c|c|c|c|c|c|c|c|}
\hline $\begin{array}{c}\text { Strongly } \\
\text { Agree }\end{array}$ & $\#$ & $\begin{array}{l}\text { Somewhat } \\
\text { Agree }\end{array}$ & \# & $\begin{array}{l}\text { Neither } \\
\text { Agree } \\
\text { or } \\
\text { Disagree }\end{array}$ & $\#$ & $\begin{array}{l}\text { Somewhat } \\
\text { Disagree }\end{array}$ & $\#$ & Disagree & $\#$ & $\begin{array}{l}\text { Strongly } \\
\text { Disagree }\end{array}$ & \# & Total \\
\hline $39.58 \%$ & 19 & $31.25 \%$ & 15 & $2.08 \%$ & 1 & $10.42 \%$ & 5 & $12.50 \%$ & 6 & $4.17 \%$ & 2 & 48 \\
\hline
\end{tabular}

RQ2: Have you received a branded KSU face mask?

As shown in Table 2 below, within the first few weeks of Fall 2020 semester, nearly $83 \%$ of responses indicated that they had received a KSU-branded cloth face mask. Among those who had not received a KSU-branded face mask include stakeholders who were permitted to attend classes or work from home and, likely, had not come to campus to pick up their face mask.

TABLE 2

RESPONSES TO RQ2: HAVE YOU RECEIVED A BRANDED KSU FACE MASK?

\begin{tabular}{|c|c|c|c|c|c|c|c|c|c|c|c|c|}
\hline $\begin{array}{c}\text { Strongly } \\
\text { Agree }\end{array}$ & \# & $\begin{array}{c}\text { Somewhat } \\
\text { Agree }\end{array}$ & $\#$ & $\begin{array}{c}\text { Neither } \\
\text { Agree } \\
\text { or } \\
\text { Disagree }\end{array}$ & \# & $\begin{array}{l}\text { Somewhat } \\
\text { Disagree }\end{array}$ & \# & Disagree & $\#$ & $\begin{array}{l}\text { Strongly } \\
\text { Disagree }\end{array}$ & \# & Total \\
\hline $82.98 \%$ & 39 & $8.51 \%$ & 4 & $0.00 \%$ & 0 & $2.13 \%$ & 1 & $2.13 \%$ & 1 & $4.26 \%$ & 2 & 47 \\
\hline
\end{tabular}

RQ3: Do you feel that KSU has taken appropriate steps to ensure multiple daily cleaning of high-traffic areas?

As shown in Table 3 below, whereas $40.43 \%$ of responses (34 out of 47 responses) indicate that they Strongly Agree with KSU taking appropriate steps to ensure multiple daily cleaning of high-traffic areas, a combined $70.22 \%$ either Somewhat Agree or Strongly Agree.

TABLE 3

RESPONSES TO RQ3: DO YOU THAT KSU HAS TAKEN APPROPRIATE STEPS TO ENSURE MULTIPLE DAILY CLEANING OF HIGH-TRAFFIC AREAS?

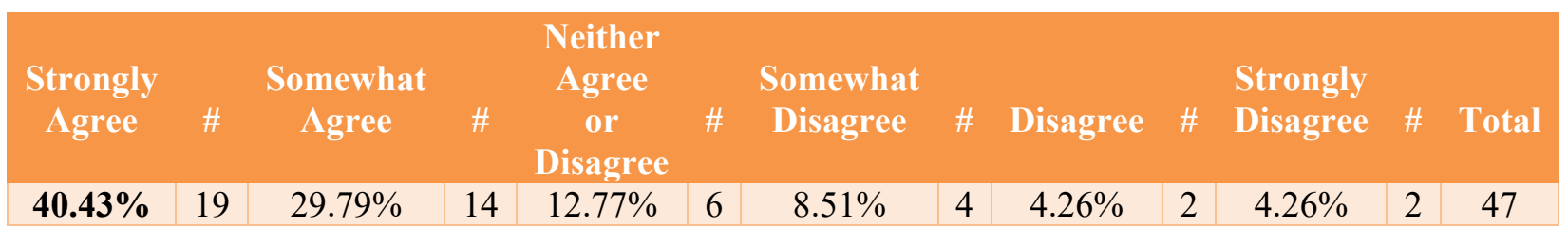

RQ4: Do you feel that the high-touch surfaces are being cleaned often enough to prevent COVID-19 from spreading?

Opinions vary for this question. Whereas $50 \%$ of the responses indicate either Strongly Agree or Somewhat Agree with high-touch surfaces being cleaned often enough to prevent COVID-19 from spreading, $16.67 \%$ neither agreed or disagreed, and a combined $33.34 \%$ (or $1 / 3$ ) of the responses indicate varying degrees of Disagree. It is important to note that the survey ran for one day via KSU Today but it took three weeks to receive all responses to the survey, which ended six weeks into the Fall 2020 semester. 


\section{TABLE 4}

\section{RESPONSES TO RQ4: DO YOU FEEL THAT THE HIGH-TOUCH SURFACES ARE BEING CLEANED OFTEN ENOUGH TO PREVENT COVID-19 FROM SPREADING?}

\begin{tabular}{|c|c|c|c|c|c|c|c|c|c|c|c|c|}
\hline $\begin{array}{c}\text { Strongly } \\
\text { Agree }\end{array}$ & $\#$ & $\begin{array}{c}\text { Somewhat } \\
\text { Agree }\end{array}$ & \# & $\begin{array}{c}\text { Neither } \\
\text { Agree } \\
\text { or } \\
\text { Disagree }\end{array}$ & $\#$ & $\begin{array}{l}\text { Somewhat } \\
\text { Disagree }\end{array}$ & $\#$ & Disagree & \# & $\begin{array}{l}\text { Strongly } \\
\text { Disagree }\end{array}$ & $\#$ & Total \\
\hline $29.17 \%$ & 14 & $20.83 \%$ & 10 & $16.67 \%$ & 8 & $16.67 \%$ & 8 & $10.42 \%$ & 5 & $6.25 \%$ & 3 & 48 \\
\hline
\end{tabular}

RQ5: What changes have impacted you the most on-campus due to COVID-19?

As shown in Table 5 below, 6 of the 13 responses (or $46.12 \%$ ) to this question indicate stress, worry, or fear concerns with having to wear face masks or being in an unsafe environment. Two responses (or $15.38 \%$ ) indicate limited interaction with students. The remaining responses (38.5\%) include concerns over a lack of required COVID-19 testing while returning to campus, changes in the protocol at the campus library, and concerns over poor planning and distrust of the KSU administration.

TABLE 5

\section{RESPONSES TO RQ5: WHAT CHANGES HAVE IMPACTED YOU THE MOST ON-CAMPUS} DUE TO COVID-19?

\begin{tabular}{|l|c|c|}
\hline \multicolumn{1}{|c|}{ Changes } & Percentage & Count \\
\hline Stress/worry/fear of being in an unsafe environment & $15.38 \%$ & 2 \\
\hline Having to wear a face mask and mic when giving lectures & $15.38 \%$ & 2 \\
\hline Being around people who don't wear face masks & $15.38 \%$ & 2 \\
\hline Limited interaction with students & $15.38 \%$ & 2 \\
\hline Social distancing issues & $7.69 \%$ & 1 \\
\hline Lack of required testing & $7.69 \%$ & 1 \\
\hline Poor planning by KSU administration & $7.69 \%$ & 1 \\
\hline Distrust in KSU administration & $7.69 \%$ & 1 \\
\hline The way we interact and use resources in the library & $7.69 \%$ & 1 \\
\hline
\end{tabular}

\section{CONCLUSIONS}

This IRB-approved study was conducted early into the Fall 2020 semester at Kennesaw State University. Students and KSU employees had just returned to campus following a summer where quarantining was the norm as the number of positive COVID-19 cases rose sharply nationwide, in fact, worldwide. The KSU administration created various task forces during the Spring and Summer months to devise a plan for a safe return to campus. During the Fall 2020 semester, many classes were conducted $100 \%$ online and many classes were conducted face-to-face on-campus with safety protocols in place, such as the requirement for all people to wear face masks while on campus, maintaining 6 feet of space between persons for social distancing, and frequent washing of hands and face.

A Qualtrics survey was created by an industrial engineering professor and two senior-level industrial engineering students to assess the climate on campus of returning stakeholders, amid the COVID-19 pandemic. The results were received at about $1 / 3$ of the way in the semester. A total of 48 usable responses were received from a one-day posting of the survey in KSU Today, the daily online medium that KSU uses to post Announcements of interest to the KSU community. All results were in three weeks after the oneday posting. 
Although there was much trepidation, the survey results from RQ1 indicate a general sense of feeling safe when coming to campus $(\sim 71 \%)$. From RQ2, most of the respondents $(\sim 83 \%)$ had received their KSU-branded cloth face mask by the time they took the survey. In response to RQ3, 50\% of the respondents indicated a feeling that KSU had taken appropriate steps to ensure multiple daily cleanings of high-traffic areas. From RQ4, about $46 \%$ of respondents felt that high-touch surfaces were being cleaned frequently enough to prevent COVID-19 from spreading. The free response question, RQ5, indicated about $46 \%$ of respondents noted changes in stress level, worry, and fear about returning to a potentially unsafe environment. Limited interaction with students, social distancing issues, and either poor planning or distrust of the KSU administration were also cited as changes upon respondents' return to campus.

\section{RESEARCH LIMITATIONS}

The research team comprised a full-time engineering professor and two senior-level industrial engineering students. Whereas this study consists of real-life responses from a major university with a student enrollment of over 41,000 students in the state of Georgia, one research limitation is that the sample size of 48 responses is relatively small; however, the survey was posted for only one day. Posting the survey daily via KSU Today over a longer duration would likely have generated more responses. Another research limitation may be whether our research findings can be generalized across all academic institutions.

\section{REFERENCES}

Alexander, B. (2020). How the coronavirus will change faculty life forever. Chronicle of Higher Education, 66(29).

Aufderheide, D., \& Gondles, E. (2020, May/June). The psychology of COVID-19. Corrections Today, pp. $8-13$.

Auon, J.E. (2020, August 18). Why college campuses can't wait. The Washington Post. Retrieved from wapo.28810dd0-e17d-11ea-8181-606e603bb1c4

Borowiak, M., Ning, F., Pei, J., Zhao, S., Tung, H-R., \& Durett, R. (2020). Controlling the spread of COVID-19 on college campuses. arXiv.2008.07293v1.

Camera, L. (2020, August 19). Universities wave the white flag in the face of campus coronavirus outbreaks. U.S. News \& World Report.

Centers for Disease Control and Prevention. (n.d.). Coronavirus disease 2019 (COVID-19). Retrieved from cdc.gov/coronavirus/2019-ncov/prevent-getting-sick/prevention.html

Corbet, S., \& Siegel, T. (2020, September 18). Virus clusters at French universities give Europe a lesson. The Canadian Press.

Court, E., \& Lorin, J. (2020, August 19). Colleges embrace Covid testing as key for safe returns to campus. Bloomberg.com.

Diep, F. (2020). How do you quarantine for coronavirus on a college campus? Chronicle of Higher Education, 66(25), 1.

Dixon, J.A. (2020, July). Campus concerns. Library Journal, pp. 18-19.

Gale Literature Resource Center. (2020, August 23). College road trip: UNC students move out after COVID-19 outbreak (Weekend Edition Sunday). Retrieved from https://link.gale.com/apps/doc/A633424533.LitRC?u=kennesaw_main\&sid=LitRC\&xid=a37adal c

Gale Literature Resource Center. (2020, August 26). British universities weigh risks of welcoming students back to campus amid Coronavirus. PRI's The World. Retrieved from https://link.gale.com/apps/doc/A633590405/LitRC?u-

kennesaw_main\&sid=LitRC\&xid=393b04ba

Gale Literature Resource Center. (2020, September 4). How colleges react to coronavirus outbreaks on campuses. All Things Considered. Retrieved from 
https://link.gale.com/apps/doc/A734720980/LitRC?u=kennesaw_main\&sid=LitRC\&xid=d9582 1 $6 \mathrm{~d}$

Gale Literature Resource Center. (2020, September 6). How the University of Arizona is handling COVID-19 on campus (Weekend Edition Sunday).

Gould, K.J. (2020, May). COVID-19 and college students with special needs. EP Magazine, pp. 44-46.

Grayer, A., \& Stuart, E. (2020, August 19). Hundreds of Covid-19 cases reported as students return to college campuses. CNN Wire.

Kennedy, M. (2020). Classes dismissed. American School \& University, pp. 14-17.

KSU. (2020). COVID-19 resource guide for students.

KSU. (2020). KSU Guide for returning to the workplace.

Marek, L. (2020). Campus is calling, despite the dangers: Amid lingering COVID worries, universities plan to bring back students - and reluctant faculty. Crain's Chicago Business, 43(28).

Nadworny, E., \& Inskeep, S. (2020, September 9). Despite mass testing, University of Illinois sees coronavirus cases rise. Morning Edition (NPR).

Nocera, J. (2020, May 25). The myth of the empty campus. Bloomberg Businessweek.

PR Newswire. (2020, July 27). 1,000+ Colleges and universities sign-up for \#CampusClear, a free selfscreening mobile app built by Ivy.ai.

Raimonde, O. (2020, August 30). Colleges with Covid outbreaks advised to keep students on campus. Bloomberg.com.

Reilly, K. (2020). Coronavirus outbreaks linked to fraternity houses are a warning for college campuses. Time.com, 0040781X.

Roetert, E.P., Bell, L., \& Hainline, B. (2020). COVID-19 and its impact on players' mental health. ITF Coaching and Sport Science Review 2020, 81(28), 19-21.

Shuja, K.H., Aqeel, M., Jaffar, A., \& Ahmed, A. (2020). COVID-19 pandemic and impending global mental health implications. Psychiatria Danubina, 32(1), 32-35.

Vaghela, V. (2020, May 20). Cambridge University moves all lectures online until 2021. Bloomberg.com.

Weissman, S. (2020, June 11). Safe space. Diverse: Issues in Higher Education, pp. 18-19.

Wood, S. (2020, June 11). Finding an ally. Diverse: Issues in Higher Education, pp. 22-23.

World Health Organization. (2020, March 11). WHO director-general's opening remarks at the media briefing on COVID-19. Retrieved from who.int/dg/speeches/detail/who-director-general-sopening-remarks-at-the-media-briefing-on-covid-19---11 march - 2020 